\title{
THE BIOLOGICAL PROFILE OF 8-AZA QUINESTROL
}

\author{
T. W. MISGHLER AND D. GAWLAK \\ Physiology Department, Warner-Lambert Research Institute, \\ Morris Plains, $\mathcal{N} . \mathcal{F}$.
}

(Received 1st April 1969)

\begin{abstract}
Summary. The biological properties of 8-aza quinestrol (AQ) were compared to quinestrol $(Q)$ and ethynyloestradiol (EE). AQ is an orally active oestrogenic steroid, which is taken up and released from body fat and therefore has some prolonged effects. Storage of AQ, however, was less than that reported for $\mathbf{Q}$ and, as a consequence, $\mathbf{Q}$ had considerably more prolonged action. AQ was less potent than either steroid in the immature rat uterotrophic assay. In the adult rat, AQ was less potent than $Q$ but more potent than $E E$ for prevention of pituitary-related responses (fertility, ovulation and ovarian hypertrophy after hemicastration). It was concluded that substitution of a nitrogen atom in the 8 position decreased both the biological and fat storage properties of $Q$.
\end{abstract}

\section{INTRODUGTION}

The etherification of oestrogenic steroids was initially described by Ercoli \& Gardi (1961). Numerous reports on these compounds have appeared and are reviewed by Meli \& Steinetz (1966). The 3-cyclopentyl ether of ethynyloestradiol, quinestrol, was shown to be the most potent oral oestrogen studied. Its uterotrophic response in mice was twice that of the parent steroid. The reason for this increase in potency was shown by Meli, Wolff, \& Honrath (1963) to be due to its storage in, and subsequent release from, body fat. The prolongation of activity makes quinestrol a suitable oral contraceptive to give at monthly intervals (Greenblatt, 1967). Recently, the synthesis of a new class of steroids, with a nitrogen at the 8 position, was reported by Brown, Lustgarten, Stanaback \& Meltzer (1966) and Bowler, Clarkson \& Doyle (1968). The 8-aza analogue of quinestrol (AQ) (3-[cyclopentyloxy]-17-ethynyl-8. azaestra-1,3,5(10)-trien-17-ol) has been synthesized, and the purpose of this report is to compare its biological properties with quinestrol (Q) and ethynyloestradiol (EE).

\section{MATERIALS AND METHODS}

All compounds were dissolved in sesame oil and administered orally, except as noted. Sprague-Dawley derivative rats (KG Farms, Parsippany, N.J.) were employed and were maintained at $72^{\circ}$ to $78^{\circ} \mathrm{F}, 12 \mathrm{hr}$ light $/ 12 \mathrm{hr}$ dark, and 
received unrestricted food and water. Body weights ranged from 180 to $220 \mathrm{~g}$ for adult, and 30 to $35 \mathrm{~g}$ for immature rats.

The following biological parameters were studied:

Uterotrophic activities were determined in intact, immature, female rats, which were treated for 3 days, either orally or subcutaneously. The uteri were removed on Day 4 and weighed to the nearest $0.5 \mathrm{mg}$ after fluid had been expressed.

Anti-ovulatory activity was determined in adult rats by the method of Bennett, Vallance \& Vickery (1967).

Anti-fertility activity was determined after both multiple and single dosing. For multiple dosing, the female rats were treated for 30 days and caged with males on Day 16. The date of parturition was noted and conception was assumed to be 23 days earlier. Activity resulting from a single dosing was determined by placing males with females 1 day after a single treatment of the female. When the females became pregnant, they were separated and allowed to come to term.

Inhibition of ovarian hypertrophy after hemicastration was performed according to Peterson, Edgren \& Jones (1964).

Fat storage of AQ was determined by the method of Meli et al. (1963). Adult, female rats were treated orally with either $2 \mathrm{mg}$ or $6 \mathrm{mg}$ of the steroid. Groups of five rats were killed 24 and $72 \mathrm{hr}$ after treatment. Perirenal fat was removed, pooled and homogenized with methylene chloride. After evaporation of the solvent, the residue was diluted with appropriate amounts of sesame oil and assayed orally for uterotrophic activity. The amount of AQ in the fat was determined from a reference curve as described by Meli et al. (1963). The total amount of fat per 200-g rat was assumed to be $15 \mathrm{~g}$ (Mickelsen \& Anderson, 1959).

Prolonged oestrogen response was determined after administering a single oral dose of $100 \mu \mathrm{g}$ of each steroid to rats 2 weeks after ovariectomy. Groups of seven rats were killed on various days after treatment at which time vaginal smears were made and the weight of the uterus, from which fluid had been expressed, was recorded. Vaginal smears were classified as oestrogenic (nucleated epithelial and/or cornified cells) or anoestrous (leucocytes).

\section{RESULTS}

Text-figure 1 presents the uterotrophic responses of the orally administered steroids. Since the dose-response curves of $\mathrm{AQ}$ and $\mathrm{Q}$ were not parallel to $\mathrm{EE}$, potency estimates were calculated at a uterine weight of $58 \mathrm{mg}$. On this basis, EE was $80 \%$ and AQ 25\% as potent as Q. However, EE had a lower threshold and was therefore a more active agent at lower dosage levels. Uterotrophic activity after subcutaneous treatment (Text-fig. 2) resulted in alterations in potency relationship. The response curves of $A Q$ and $Q$ were again steeper, but EE had considerably more activity than the other steroids at all dose levels. $Q$ was still more potent than AQ but the difference was less, and although direct comparisons were not made, both cyclopentyl ethers had less activity after subcutaneous treatment, with $Q$ decreasing the most. 
The ability of these steroids to prevent ovulation in the rat is presented in Table 1. At the dose levels employed, complete inhibition of ovulation was not

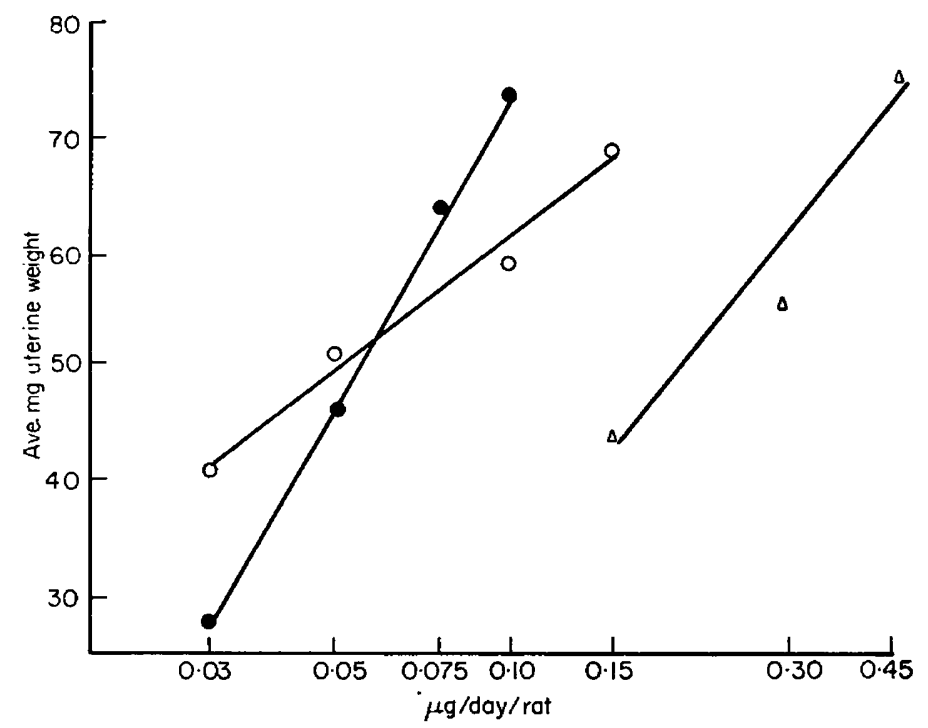

Texr-pIG. 1. Uterotrophic activities after oral administration to immature rats. $\bullet, Q$; O, EE, $\triangle$, AQ.

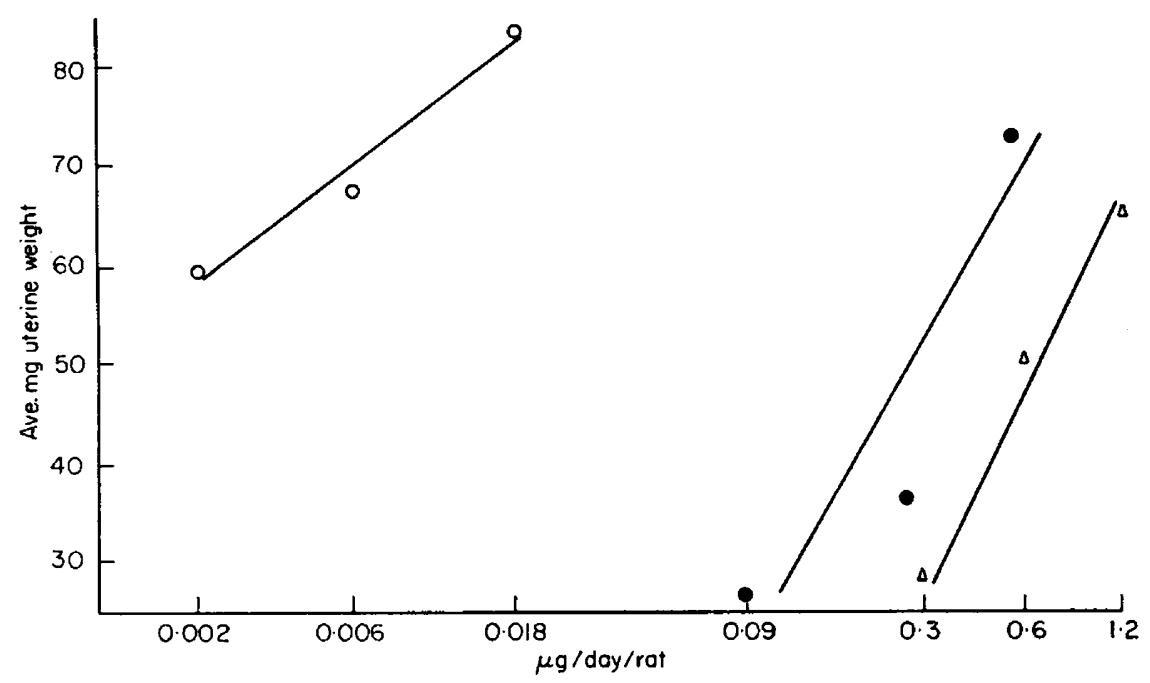

TeXT-FIG. 2. Uterotrophic activities after subcutaneous administration to immature rats.

$\bullet, Q ; O, E E ; \triangle, A Q$.

possible. Higher dosage for $A Q$ and $Q$ were not practical since hair and weight loss were much in evidence at the $50-\mu \mathrm{g}$ dose. These data suggest that $Q$, followed by $A Q$ and EE, was the most potent in its ability to decrease the number of ovulations per rat.

Table 2 presents anti-fertility responses after multiple dosing. Again, $Q$ was 
the most potent, followed by $\mathrm{AQ}$ and EE. All the females became pregnant, demonstrating a return to fertility after treatment. Table 3 shows that all of the single dose treatments of $Q$ and the high dose of $A Q$ significantly increased

TABLE 1

INHIBITION OF OVULATION

\begin{tabular}{|c|c|c|c|}
\hline Treatment & $\begin{array}{c}\text { Dose } \\
(\mu g / \text { rat } / \text { day })\end{array}$ & $\begin{array}{c}\% \text { Rats } \\
\text { ovulating }\end{array}$ & $\begin{array}{c}\text { Ovulations } \\
\text { rat ovulated } \\
A v . \pm S . E .\end{array}$ \\
\hline Control & - & $100(26 / 26)^{*}$ & $20 \cdot 6 \pm 1 \cdot 1$ \\
\hline 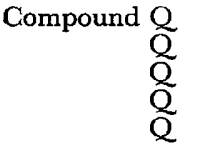 & $\begin{array}{r}0 \cdot 4 \\
1 \cdot 0 \\
4 \cdot 0 \\
16 \cdot 0 \\
50 \cdot 0\end{array}$ & $\begin{array}{l}100(10 / 10) \\
100(15 / 15) \\
100(8 / 8) \\
100(6 / 6) \\
75(6 / 8)\end{array}$ & $\begin{array}{r}16 \cdot 6 \pm 2 \cdot 7 \\
12 \cdot 4 \pm 0 \cdot 9 \\
9 \cdot 4 \pm 2 \cdot 4 \\
8 \cdot 5 \pm 1 \cdot 9 \\
7 \cdot 5 \pm 2 \cdot 0\end{array}$ \\
\hline $\begin{array}{l}\mathbf{E E} \\
\mathbf{E E} \\
\mathbf{E E} \\
\mathbf{E E} \\
\mathbf{E E}\end{array}$ & $\begin{array}{r}0 \cdot 4 \\
1 \cdot 0 \\
4 \cdot 0 \\
16 \cdot 0 \\
50 \cdot 0\end{array}$ & $\begin{array}{l}100(9 / 9) \\
100(16 / 16) \\
100(11 / 11) \\
87(7 / 8) \\
100(8 / 8)\end{array}$ & $\begin{array}{r}16 \cdot 5 \pm 1 \cdot 2 \\
16 \cdot 5 \pm 1 \cdot 3 \\
13 \cdot 0 \pm 1 \cdot 2 \\
8 \cdot 0 \pm 1 \cdot 5 \\
15 \cdot 0 \pm 1 \cdot 6\end{array}$ \\
\hline $\begin{array}{l}A Q \\
A Q \\
A Q \\
A Q \\
A Q\end{array}$ & $\begin{array}{r}0.4 \\
1.0 \\
4 \cdot 0 \\
16 \cdot 0 \\
50 \cdot 0\end{array}$ & $\begin{array}{l}100(10 / 10) \\
100(16 / 16) \\
78(7 / 9) \\
100(7 / 7) \\
100(6 / 6)\end{array}$ & $\begin{array}{r}20 \cdot 2+1 \cdot 1 \\
16 \cdot 8 \pm 1 \cdot 4 \\
7 \cdot 1 \pm 1 \cdot 8 \\
9 \cdot 6 \pm 3 \cdot 0 \\
17 \cdot 0 \pm 1 \cdot 8\end{array}$ \\
\hline
\end{tabular}

* Number of rats ovulated/total number treated.

TABLE 2

ANTI-FERTILITY AGTIVITY AFTER MULTIPLE ORAL DOSING

\begin{tabular}{|c|c|c|c|c|}
\hline \multirow[b]{2}{*}{ Treatment } & \multirow[b]{2}{*}{$\begin{array}{c}\text { Rats } \\
\text { treated }\end{array}$} & \multirow[b]{2}{*}{$\begin{array}{c}\text { Dosage } \\
(\mu \mathrm{g} / \mathrm{rat} / \text { day })\end{array}$} & \multicolumn{2}{|c|}{ Pregnancies } \\
\hline & & & $\begin{array}{c}\text { During } \\
\text { treatment }\end{array}$ & $\begin{array}{c}\text { After } \\
\text { treatment }\end{array}$ \\
\hline Control & 9 & - & 7 & 2 \\
\hline 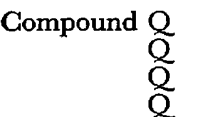 & $\begin{array}{r}10 \\
10 \\
10 \\
6\end{array}$ & $\begin{array}{r}0.4 \\
1 \cdot 0 \\
4 \cdot 0 \\
16 \cdot 0\end{array}$ & $\begin{array}{l}2 \\
7 \\
0 \\
0\end{array}$ & $\begin{array}{r}8 \\
3 \\
10 \\
6\end{array}$ \\
\hline $\begin{array}{l}\widehat{\mathrm{EE}} \\
\mathrm{EE} \\
\mathrm{EE} \\
\mathrm{EE}\end{array}$ & $\begin{array}{l}8 \\
9 \\
8 \\
8\end{array}$ & $\begin{array}{r}0 \cdot 4 \\
1 \cdot 0 \\
4 \cdot 0 \\
16 \cdot 0\end{array}$ & $\begin{array}{l}7 \\
8 \\
7 \\
1\end{array}$ & $\begin{array}{l}1 \\
1 \\
1 \\
7\end{array}$ \\
\hline $\begin{array}{l}\mathrm{AQ} \\
\mathrm{AQ} \\
\mathrm{AQ} \\
\mathrm{AQ}\end{array}$ & $\begin{array}{l}9 \\
9 \\
8 \\
7\end{array}$ & $\begin{array}{r}0 \cdot 4 \\
1 \cdot 0 \\
4 \cdot 0 \\
16 \cdot 0\end{array}$ & $\begin{array}{l}7 \\
0 \\
7 \\
0\end{array}$ & $\begin{array}{l}2 \\
9 \\
1 \\
7\end{array}$ \\
\hline
\end{tabular}

the length of time for conception to occur. These results clearly indicated prolonged anti-fertility action for both $\mathrm{AQ}$ and $\mathrm{Q}$. Table 4 presents the data relating to the inhibition of ovarian hypertrophy after hemicastration. Again, $Q$ was seen to be the most active, followed by AQ and EE.

Table 5 presents data which indicate that an oestrogenic agent was present 
TABLE 3

ANTI-FERTILITY ACTIVITY AFTER SINGLE ORAL DOSING

\begin{tabular}{l|c|c|c}
\hline \multicolumn{1}{c|}{ Treatment } & $\begin{array}{c}\text { Rats } \\
\text { treated }\end{array}$ & $\begin{array}{c}\text { Dose } \\
(\mu \mathrm{g} / \text { rat })\end{array}$ & $\begin{array}{c}\text { Av. no. days after treatment } \\
\text { parturition occurred } \pm \text { S.E. }\end{array}$ \\
\hline Control & 9 & - & $27 \cdot 9 \pm 2 \cdot 2$ \\
Compound Q & 10 & 30 & $34 \cdot 5 \pm 1 \cdot 9 *$ \\
Q & 10 & 100 & $42 \cdot 7 \pm 1 \cdot 7^{*}$ \\
E & 10 & 300 & $42 \cdot 7 \pm 2 \cdot 1 *$ \\
EE & 9 & 30 & $27 \cdot 9 \pm 2 \cdot 1$ \\
EE & 9 & 100 & $29 \cdot 6 \pm 3 \cdot 1$ \\
AQ & 10 & 300 & $32 \cdot 1 \pm 2 \cdot 5$ \\
AQ & 10 & 30 & $30 \cdot 5 \pm 2 \cdot 0$ \\
AQ & 10 & 100 & $30 \cdot 6 \pm 1 \cdot 8$ \\
& 9 & 300 & $36 \cdot 8 \pm 1 \cdot 2 *$ \\
\hline
\end{tabular}

* Significantly different $(P \leqslant 0 \cdot 05)$ from control ( $t$-test, one-sided).

TABLE 4

INHIBITION OF OVARIAN COMPENSATORY HYPERTROPHY IN HEMICASTRATED RATS

\begin{tabular}{|c|c|c|c|c|c|}
\hline Treatment & $\begin{array}{c}\text { Dosage } \\
(\mu g / \text { rat } / \text { day })\end{array}$ & $\begin{array}{l}\text { No. } \\
\text { rats }\end{array}$ & $\begin{array}{c}\text { Ovarian } \\
w t(m g) \\
A v . \pm S . E .\end{array}$ & $\begin{array}{l}\text { Relative } \\
\text { potency }\end{array}$ & $95 \% C L$ \\
\hline \multirow{2}{*}{$\begin{array}{l}\text { Controls intact } \\
\text { Controls castrated }\end{array}$} & - & 12 & $36 \cdot 2 \pm 1 \cdot 4$ & - & - \\
\hline & & 8 & $53 \cdot 5 \pm 2 \cdot 9$ & - & - \\
\hline \multirow{2}{*}{$\begin{array}{l}\text { Compound } Q \\
Q \\
\stackrel{Q}{Q} \\
\text { EE } \\
\mathbf{E E} \\
\mathbf{E E}\end{array}$} & $\begin{array}{l}0.4 \\
1 \cdot 0 \\
4 \cdot 0\end{array}$ & $\begin{array}{l}5 \\
5 \\
5\end{array}$ & $\begin{array}{l}51 \cdot 7 \pm 1 \cdot 9 \\
48 \cdot 7 \pm 6 \cdot 0 \\
37.9 \pm 3.9\end{array}$ & 100 & \\
\hline & $\begin{array}{r}1 \cdot 0 \\
4 \cdot 0 \\
16 \cdot 0\end{array}$ & $\begin{array}{l}5 \\
5 \\
5\end{array}$ & $\begin{array}{l}55 \cdot 6 \pm 3.7 \\
50 \cdot 4 \pm 1.5 \\
40.4 \pm 2.9\end{array}$ & $18^{*}$ & 5 to 67 \\
\hline $\begin{array}{l}\mathrm{AQ} \\
\mathrm{AQ} \\
\mathrm{AQ}\end{array}$ & $\begin{array}{r}1 \cdot 0 \\
4 \cdot 0 \\
16 \cdot 0\end{array}$ & $\begin{array}{l}4 \\
5 \\
5\end{array}$ & $\begin{array}{l}54 \cdot 8 \pm 4 \cdot 5 \\
43 \cdot 4 \pm 1 \cdot 4 \\
34 \cdot 6 \pm 3 \cdot 3\end{array}$ & 42 & 11 to 155 \\
\hline
\end{tabular}

* Significantly different from $Q(P \leqslant 0.05)$.

TABLE 5

STEROID CONCENTRATION IN BODY FAT OF RATS FOLLOWING A SINGLE ORAL ADMINISTRATION OF 2 AND 6 MG/ANIMAL

\begin{tabular}{|c|c|c|c|c|c|}
\hline & \multirow{2}{*}{$\begin{array}{c}\text { Hr after } \\
\text { dosage }\end{array}$} & \multicolumn{4}{|c|}{$\mu g$ of steroid/total amount fat/animal* } \\
\hline & & Control & $A Q$ & $Q \dagger$ & $E E \dagger$ \\
\hline $2 \mathrm{mg}$ & $\begin{array}{l}24 \\
72\end{array}$ & $\begin{array}{l}0 \\
0\end{array}$ & $\begin{array}{l}75 \cdot 0 \\
36 \cdot 0\end{array}$ & $\begin{array}{l}416 \cdot 0 \\
267 \cdot 0\end{array}$ & $\begin{array}{l}0 \\
0\end{array}$ \\
\hline $6 \mathrm{mg}$ & $\begin{array}{l}24 \\
72\end{array}$ & $\begin{array}{l}0 \\
0\end{array}$ & $\begin{array}{r}240 \cdot 0 \\
60 \cdot 0\end{array}$ & $\begin{array}{l}865 \cdot 0 \\
592 \cdot 0\end{array}$ & $\begin{array}{l}0 \\
0\end{array}$ \\
\hline
\end{tabular}

* Assume $15 \mathrm{~g}$ fat/rat.

$\dagger$ Data for $Q$ and EE taken from Meli et al. (1963). 
in the fat of rats after AQ treatment. The dose-response curves of uterine weights obtained from treatment of rats with the extracted fat were generally parallel to the reference curve of $A Q$. These data suggest that $A Q$ was stored

TABLE 6

VAGINAL RESPONSES AFTER A SINGLE $100 \mu$ G ORAL ADMINISTRATION OF EACH STEROID TO OVARIECTOMIZED RATS

\begin{tabular}{c|c|c|c|c}
\hline $\begin{array}{c}\text { Days post } \\
\text { treatment }\end{array}$ & Controls & $Q$ & $E E$ & $A Q$ \\
\hline 1 & $0 / 5$ & $2 / 5^{*}$ & $2 / 5$ & $1 / 6$ \\
2 & $0 / 5$ & $7 / 0$ & $7 / 0$ & $7 / 0$ \\
3 & $0 / 5$ & $7 / 0$ & $7 / 0$ & $6 / 1$ \\
5 & - & $7 / 0$ & $1 / 6$ & $3 / 4$ \\
7 & $0 / 5$ & $7 / 0$ & $1 / 6$ & $0 / 7$ \\
9 & - & $6 / 1$ & $0 / 7$ & $0 / 7$ \\
12 & $0 / 5$ & $3 / 4$ & $0 / 7$ & $0 / 7$ \\
15 & $-5 / 3$ & $0 / 7$ & $0 / 7$ & $0 / 7$ \\
19 & $0 / 5$ & $0 / 7$ & $0 / 7$ & $1 / 6$ \\
\hline
\end{tabular}

* Number oestrogenic stimulated/number anoestrous.

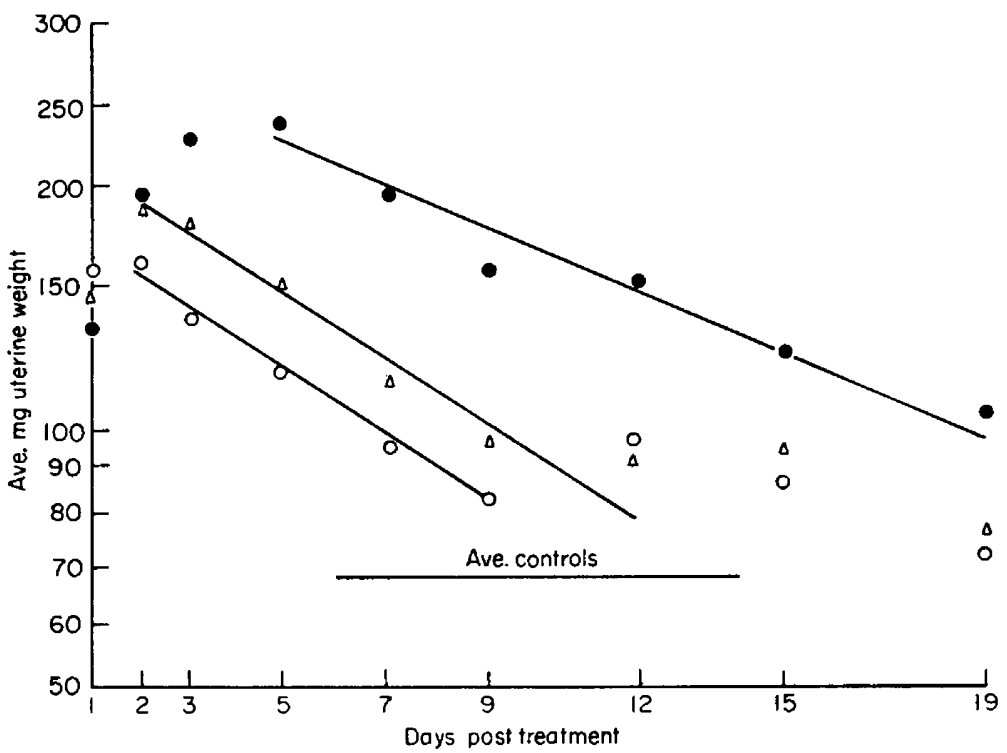

TEXT-FIG. 3. Uterotrophic activity after a single $(100 \mu \mathrm{g})$ dose to adult ovariectomized rats. $\bullet, Q ; O, E E ; \triangle, A Q$.

in, and subsequently released from, fat after oral administration. This storage was about $1 / 5$ the amount of that reported for $Q$. The release of $A Q$ from fat also appeared to occur at a faster rate than reported for $Q$.

Table 6 and Text-fig. 3 demonstrate that $Q$ has considerable, prolonged oestrogenic activity in ovariectomized rats. The rate of uterine weight regression was significantly less $(P \leqslant 0 \cdot 05)$, maximal stimulation and the return to anoestrus was delayed longer and $Q$ was significantly more active $(P \leqslant 0.05)$ 
than AQ or EE. AQ showed some limited prolonged response since oestrogenic smears were present longer and the maximal response was significantly greater $(P \leqslant 0.05)$ when compared to EE. This prolongation of action, however, was not as great as that which was evident for $Q$.

\section{DISCUSSION}

These studies reveal a general decline in the activity of $A Q$ in all test parameters when compared to $Q$. Other investigators (Bowler et al., 1968) have also reported decreases in activities in 8-aza steroids. Accompanying this decline, there was a corresponding decrease in the affinity of $A Q$ for fat.

The difference in biological activity and the consequence of fat storage was best seen in the uterotrophic responses. It is apparent that AQ had less activity than either $Q$ or EE and that the dose-response curves for both cyclopentyl ethers were steeper than that of EE. The potency relationship between $Q$ and $\mathrm{EE}$, after oral treatment, is in agreement with that of Steinetz, Meli, Beach \& Giannina (1966), and the decreased response of $Q$ after subcutaneous treatment confirmed a similar observation by Ercoli, Gardi \& Bruni (1964). Uterotrophic responses demonstrated four factors which appear to be related to the fat storage properties of both $A Q$ and $Q:(1)$ the steep dose-response curves; (2) a higher threshold of response to $Q$ after oral dosage; (3) decreased activity after subcutaneous treatment, and (4) decreased affinity of AQ for fat, manifesting itself in a lesser decline in response after subcutaneous injection. Junkmann \& Witzel (1958) have also described similar characteristics for compounds which are stored and have prolonged activity after injection.

It was demonstrated that $A Q$, like $Q$, was taken up and released from fat after oral administration, though less was taken up and it was released at a faster rate than $Q$. Prolongation of action of $Q$ in humans (Greenblatt, 1967; Epstein, 1967) has been described. A similar phenomenon was obtained in our animal studies for $A Q$ and $Q$ in both their anti-fertility and oestrogenic activities. However, the substitution of a nitrogen atom in $Q$ reduces its fat storage properties and, as a consequence, its prolongation of biological response.

The activities determined in the adult rat (contraceptive, anti-ovulatory and inhibition of ovarian hypertrophy) have shown AQ to be less potent than $Q$ but, in contrast to its oral uterotrophic effect, more active than EE. This change in potency relationships may be a consequence of the non-parallelism of the dose-response curves of the compounds as seen in Text-fig. 1. Since these responses are believed in general to be mediated by anterior pituitary inhibition (Saunders, 1964; Bennett, Vallance \& Vickery, 1968; Benson, Sorrentino \& Evan, 1969), it is not surprising that they correlate well with each other. It was, therefore, apparent that the substitution of the nitrogen atom in $Q$ resulted in activities somewhat greater than EE but less than that of $Q$.

\section{ACKNOWLEDGMENTS}

The authors wish to thank Dr R. Brown, Department of Organic Chemistry, Warner-Lambert Research Institute for his synthesis of 8-aza quinestrol. We 
also appreciate the technical assistance of $\mathrm{Mr}$ Paul Nemith and the statistical analysis by Mr Neil Stasilli.

\section{REFERENCES}

Bennett, J. P., Vallance, D. K. \& Vickery, B. H. (1967) A method for the direct observation of ovulation inhibition in the mature rat. 7. Reprod. Fert. 13, 567.

Bennett, J. P., Vallange, D. K. \& Vickery, B. H. (1968) Investigation of block of gonadotrophin release in mature female rats. $\mathcal{J}$. Reprod. Fert. $15,233$.

Benson, B., Sorrentino, S. \& Evan, J. S. (1969) Increase in serum FsH following unilateral ovariectomy in the rat. Endocrinology, 84, 369.

Bowler, J., Cllarkson, R. \& Doyle, P. (1968) Azasteroids. Part II. 7. chem. Soc. (C) 16, 2111.

Brown, R. E., Lustgarten, D. M., Stanaback, J. \& Meltzer, R. I. (1966) 8-Azasteroids. III. J. org. Chem. 31, 1489.

EPSTEIN, J. A. (1967) Prolonged menstrual response of patients with gonadal failure following quinestrol administration. Int. $\mathcal{F}$. Fert. 12, 176.

Ercoli, A. \& GaRdi, R. (1961) Cyclopentyl ethers of oestrogenic steroids. Chem. Ind. July 8, 1037.

Ercoli, A., Gardi, R. \& BRuni, G. (1964) Ether derivatives of steroid hormones. Res. Progr. org.-biol. E mednl Chem. 1, 156.

Greenblatt, R. B. (1967) One-pill-a-month contraceptive. Fert. Steril. 18, 207.

Junkmann, K. \& Witzel, H. (1958) The chemistry and pharmacology of steroid hormone esters. Monog. Ther, Squiff Inst. Suppl. to Vol. 3.

Meli, A. \& Steinetz, B. (1966) Influence of etherification or 3-enol etherification on the biology and metabolism of steroids. Trans. N.Y. Acad. Sci. 28, 623.

Meli, A., Wolff, A. \& Honrath, W. L. (1963) The mechanism by which 3-etherification with cyclopentyl alcohol enhances the oral activity of ethynylestradiol. Steroids, 2, 417.

Mickelsen, O. \& Anderson, A. (1959) A method for preparing intact animals for carcass analysis. 7. Lab. clin. Med. 53, 282.

Peterson, D. L., Edgren, R. A. \& Jones, R. C. (1964) Steroid induced block of ovarian compensatory hypertrophy in hemicastrated female rats. 7 . Endocr. 29, 255.

Saunders, F. J. (1964) Effects of steroids on pituitary gonadotrophin and fertility. Recent Prog. Horm. Res. 20, 395.

Steinetz, B. G., Meli, A., Beach, V. L. \& Giannina, T. (1966) Influence of vehicle of administration on intestinal absorption, fat storage and biological activity of ethynylestradiol (EE) and its 3-cyclopentyl ether (EECPE) in rats. Proc. Soc. exp. Biol. Med. 134, 163. 